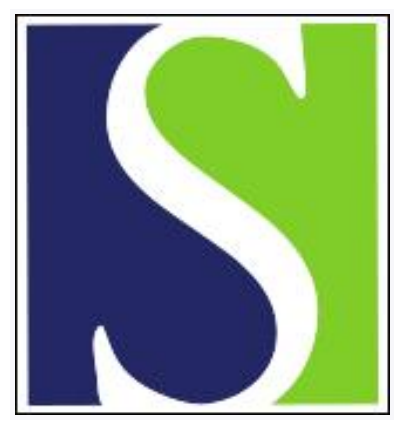

Scand J Work Environ Health 2006;32(6):421-430

https://doi.org/10.5271/sjweh.1048

Issue date: 31 Dec 2006

New systems of work organization and workers' health by Kompier MAJ

Affiliation: Radboud University Nijmegen, Department of Work and Organizational Psychology, PO Box 9104, NL-6500 HE Nijmegen, Netherlands. M.Kompier@psych.ru.nl

Refers to the following texts of the Journal: 2005;31(1):15-29 2003;29(3):171-188 2005;31(5):329-335

The following articles refer to this text: 2006;32(6):413-419; 2006;32(6):502-514; 2008;34(3):213-223; SJWEH Supplements 2008;(6):66-74; SJWEH Supplements 2008;(6):83-90; 2009;35(4):284-293; 2012;38(3):187-192; 2012;38(4):299-313; 2012;38(4):291-297; 2014;40(1):66-73; 2015;41(4):347-355

Key terms: changing world of work; new organizational practice; new system; review; work characteristic; work organization; workers' health

This article in PubMed: www.ncbi.nlm.nih.gov/pubmed/17173199

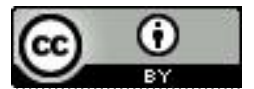




\title{
New systems of work organization and workers' health
}

\author{
by Michiel AJ Kompier, $P h D^{1}$
}

\begin{abstract}
Kompier MAJ. New systems of work organization and workers' health. Scand J Work Environ Health 2006;32(6, special issue):421-430.

This paper aims at identifying major changes in and around work organizations, their effects upon job characteristics and the health and well-being of today's employees, and related research challenges. Increased internationalization and competition, increased utilization of information and communication technology, the changing workforce configuration, and flexibility and new organizational practices are considered. As work has changed from physical to mental in nature, job characteristics have changed significantly. Meanwhile work and family life have blended. New systems of work organization have become more prevalent, but they do not represent a radical change across the whole economy. New practices may have an adverse impact upon job characteristics, but their effects depend on their design, implementation, and management. Research recommendations include improved monitoring of changes in work organization and studies into their health and safety consequences, intervention studies, studies into the motivating potential of modern work practices, studies of marginalized workers and workers in less developed countries, and "mechanism studies".
\end{abstract}

Key terms changing world of work; new organizational practice; work characteristics.

With their topical work The Social Psychology of Organizations, Katz \& Kahn (1) were among the first scientists in organizational psychology to focus on the relations between work and health. The central proposition of their chapter "Work and Health" is "that the demands and opportunities, the stresses and supports of organizational work roles affect the health of the individuals who enact these roles [p 578]". Since this pioneering work and that of scientists such as Bertil Gardell (2) and Lennart Levi (3), our understanding of the role of the psychosocial work environment has significantly increased. Nowadays, occupational stress constitutes both an acknowledged research domain and an acknowledged policy domain. Exemplary for the former, is the attention paid to occupational stress in occupational medicine journals such as the Scandinavian Journal of Work, Environment \& Health and in specialized occupational health psychology journals such as Work \& Stress. Other hallmarks are three recently published handbooks (4-6). Among examples of the latter are the Framework Agreement on Work-Related Stress, signed by the European organizations of employers and employees (7), and national legislation with respect to the psychosocial work environment. [For an overview, see the report Work-related Stress and Industrial Relations (8).]
It is now generally recognized that occupational stress is a major problem in modern organizations, both for individual employees and for management. Furthermore, there are adequate general models on the relations between work factors, personal characteristics, and short- and long-term consequences for the individual and the organization. We do know which factors in work are major risk factors for stress and its consequences for ill health (9). There is also national and international legislation that emphasizes the importance of risk assessment and risk management (primary prevention). Still, much is to be learned, especially with respect to the psychological, physiological, and behavioral mechanisms that underlie the work and health relationship and also with respect to prevention (10).

Our increased understanding of "stress at work" has not developed in a scientific vacuum (ie, in an ivory tower and irrespective of major societal transformations). On the contrary, stress research and theory development has been strongly influenced by changes in the world of work, which, in turn, followed from large economic, political, technological, and social changes in society.

Against this background, this paper has the following three objectives: (i) to document some of the major changes in and around organizations, (ii) to detect the

1 Radboud University Nijmegen, Nijmegen, Netherlands.

Reprint requests to: Michiel AJ Kompier, Radboud University Nijmegen, Department of Work and Organizational Psychology, PO Box 9104, NL-6500 HE Nijmegen, Netherlands. [E-mail: M.Kompier@psych.ru.nl] 
extent to which these changes have had an impact on job characteristics and on the health and well-being of today's employees, and, finally, (iii) to identify several research challenges in this area.

There are two points worth mentioning in advance. First, as this paper attempts to sketch along the broad lines, it does not present an exhaustive overview of the literature, and this limitation may lead to a loss of detail and some oversimplifications. Second, its focus is mainly on one part of the world, eloquently typified in the literature as the "developed industrial economies", the "advanced industrial societies", the "information economy", or the "rich postindustrial Western democracies". In this respect, this paper reflects the "bias to the rich world", which is characteristic of current literature. Thus far, working populations in poorer and less developed countries have been largely understudied by stress researchers.

\section{The changing world of work}

The world of work has changed because the world has changed. Profound changes occurring in the economic, political, technological, and social landscape include the fall of communism and the rise of new independent economies in eastern Europe, internationalization of the economy, a reduction in trade barriers between countries, the deregulation of markets, privatization of public companies and the ending of state monopolies, increased utilization of information and communication technology (ICT), increasing demands for greater accountability and efficiency in the public sector, demographic changes in the workforce, and changing consumer demand. [See also the report by Holman \& Wood (11).]

In this paper, I focus on three of these developments that have strongly influenced the organizational context (ie, increased internationalization and competition, increased utilization of ICT, and demographic changes in the workforce). I also address the organizational context itself by discussing various types of flexibility and new organizational practices (ie, strategies that modern companies choose as a reaction to the aforementioned developments).

\section{Increased internationalization and competition}

Internationalization (globalization) refers to economic activity without borders. Liberalized trade regulations and new ICT have made it possible for more companies to operate on a global scale. This trend has brought about intensified price and product competition (12). Our economic period has been termed "hypercompetition" (13), in which today's companies can compete all over the world, especially when economic conditions give them a noticeable price advantage. In search of the lowest costs, capital moves freely across international boundaries. The literature is abundant with rhetorical phrases, such as "markets in every country have become fierce battlegrounds where both domestic and foreign competitors fight for market share, and foreign competitors can be formidable [p 404]" (14). But such rhetoric is built on an empirical foundation. For example, whereas during the 1960s only $7 \%$ of the economy in the United States (US) faced international competition, in the 1980s, this percentage has increased to $70 \%$ (15). Similarly, in 2003, trade between European Union (EU) countries accounted for $67 \%$ of all EU trade. Between 1999 and 2003, EU trade with China doubled in value, and after the United States, China is now the second biggest supplier of EU imports (16).

\section{New technology}

Thomas Watson, the IBM chairman in 1943, believed that "There is a world market for maybe five computers" [quoted by Furnham (17, p 756)]. Sixty years later, in the United States, $63 \%$ of wage and salaried workers use computers in their jobs daily, whereas only $3 \%$ rarely or never use a computer at work (18). A Western Union internal memorandum from 1876 concluded that "This telephone has too many shortcomings. As a means of communication the device is inherently of no value [p 756]" (17). Both speakers proved to be wrong. During the last several decades, we have witnessed the introduction of personal computers, laptops, telefax machines, the Internet, intranets, mobile telephones, e-mail, I-mode, hand-held organizers, video conferencing, and the like. As a consequence, traditional physical constraints to business have been removed, and employees, business partners, and customers can be reached everywhere and instantly, "all day and all of the night" (the 24-hour economy). As, in many cases, work is no longer spatially, temporally, and socially distinct from nonwork, another consequence is that the traditional boundaries between work and nonwork have largely disappeared. Some illustrations from a recent study (18) follow: $35 \%$ of the US workforce use a computer at home for job-related work, whereas $18 \%$ use a computer at home to read and send job-related e-mail outside regular workhours; $32 \%$ of these employees report that they are contacted regularly about work matters outside work, while $40 \%$ say this never happens, and $28 \%$ are contacted occasionally.

\section{Changed configuration of the workforce}

Changes in the demographic profile of the workforce have led to greater diversity at work. The labor 
participation of women has increased in many countries. In the United States, for example, the wage and salaried workforce comprises almost as many women (49\%) as men (51\%) (18). Consequently, the numbers of dual-earner couples and employed persons with caregiving responsibilities are rapidly growing. However, women's work and men's work are not interchangeable identities, as the labor market is still characterized by gender segregation (19). For example, in the United States women are disproportionately represented in the growing service sector and hold less favorable jobs with lower wages and restricted benefits and flexibility (12). DiNatale (20) showed that, in the United States, the increasing pool of temporary agency contract workers is predominantly young, female, and African-American. African-American women, for example, constitute $21 \%$ of the temporary agency workforce, which is nearly twice their representation in the traditional workforce.

Globalization is also reflected in increased migration and a greater cultural diversity on the work floor (21). Furthermore, in the Western world, the level of education is increasing. Currently, female workers in the United States are better educated than male workers (18). New job starters are better educated than people who leave the workforce. In addition, due to a decline in the birth rate and greater longevity, there is a general growth in the number of older employees.

\section{Flexibility and new organizational practices}

In response and anticipation to these changes in the world (of work), modern organizations have developed a whole range of new organizational practices. These practices are found both in the profit sector and in the public and not-for-profit sector, where similar demands for cost-effectiveness and quality are evident.

New organizational practices have two things in common, greater emphasis on high performance (productivity, profit) and on flexibility. In the literature various taxonomies of such new production concepts are listed. A noteworthy example is that of Holman \& Wood (11), who distinguished among lean manufacturing, total quality management, advanced manufacturing technology, supply-chain partnering, teamwork, call centers, knowledge management, employee involvement and empowerment, teleworking, performance management, and e-business. [See The New Workplace: an Introduction (11) for a detailed discussion of these 11 types.]

In brief, the high-performance concept stands for the objective to manufacture a product or to render a service with an optimal cost-benefit ratio: high quality and low costs. Minimizing costs and maximizing productivity and profits is the adagium. Here, I concentrate on the second feature, flexibility, which refers to a more lenient, more versatile use of employees, time, and means. Different definitions of flexibility and its categorizations have been proposed in the literature. A useful taxonomy that distinguishes among five often interrelated types of flexibility has been proposed by Sparrow \& Marchington (22): structural flexibility, by introducing, either together or in isolation, flatter hierarchies and horizontal coordination between units (eg, through temporary project teams, inter-organizational networks, and team working); functional flexibility, by introducing work practices that enable effective responses to changes in demand, supply, and workload (eg, through lean manufacturing and multiskilled teams); numerical flexibility (eg, through the use of part-time and temporary employees, overtime work or outsourcing); geographic flexibility, work where it can be done most effectively (eg, by introducing telework or by dividing production and sales across different countries); and jobbased flexibility, by (re)designing jobs with better psychosocial characteristics (job variety, autonomy, feedback, etc) so that employees can control variances and deal with problems as they arise.

A more basic distinction is that between quantitative and qualitative flexibility. Examples of the former are overtime work, part-time contracts, shift work, temporary contracts, working at home, and the hiring of workers from temporary employment agencies. Examples of qualitative flexibility are job rotation, job enlargement and enrichment, and the multiskilling of employees. Today's enterprises often combine various types of flexibility.

The potential innovative character of much of these new practices is being debated in the literature (23). After all, it has already been customary for many companies to flatten organizations, for example, by removing layers of supervisors and middle managers (structural flexibility). Part-time labor and temporary contracts have also formed traditional employment relationships (numerical flexibility). The term "part-time" has been widely used since the early 1960s, whereas, in the second half of the 1980s, already around $15 \%$ of the workforce in the European Community was employed part-time (24). And, as long as multinationals have existed and as long as companies have sought the cheapest labor and the highest profits, geographic flexibility has been utilized. Job-based flexibility and functional flexibility are also by no means new concepts; multiskilling and improving psychosocial work characteristics fit nicely within the rich tradition of job (re)design (9). Therefore, to some extent, one might argue that these practices are really nothing new. What is new, however, is the pivotal position of the utilization of new technology in these new patterns. Technology is the clock that makes these new practices tick. Furthermore, one might hypothesize that, today, these longstanding archetypes and combinations thereof are 
practiced to a far greater extent and in a more systematic and intensified format than ever before. [See also The New Workplace: a Guide to the Human Impact of Modern Working Practices by Holman et al (23).]

\section{Changes in work characteristics}

Thus far, it has been argued that, as the world changes, the world of work changes and that, as the world of work changes, work itself also changes. A comparable conceptual framework has been introduced by Steve Sauter and his NORA (National Occupational Research Agenda) co-workers in their influential report The Changing Organization of Work and the Safety and Health of Working People (12). Sauter and his colleagues introduce an elegant three-level concept of organization at work that differentiates between the external context (economic, legal, technological, and demographic forces at the national and international levels), the organizational context (management structures, supervisory practices, production methods, and human resource policies), and the work context (job characteristics).

I will now focus on this third level, that of work context. The aim is to determine to what extent changes in the world of work, such as these new organizational practices, have an impact upon individual jobs and job characteristics that are likely to influence workers' health and well-being. I briefly address studies with respect to internationalization, new technology, workhome interaction (changing workforce), call centers (as one example of new organizational practices), and overtime work (as one example of quantitative flexibility).

\section{Increased internationalization and competition}

Global competition has resulted in increased downsizing and restructuring of organizations. At the same time, nontraditional employment practices that depend on temporary workers and contract labor have become more prevalent (12). For example, among a national sample of 5000 managers in the United Kingdom, over $60 \%$ had undergone major restructuring involving downsizing and outsourcing during the previous 12 months. As a consequence, almost two out of three of these middle and senior managers reported decreased job security and decreased morale and loyalty (25). The health and safety effects of downsizing and restructuring have been summarized by Sparks et al (26), who found that these trends led to an increase in job insecurity. Other studies revealed that negative effects are not only found among the victims, but also among the survivors, and the managers who implemented these measures (27-31). In a large prospective Finnish cohort study, Vahtera and his colleagues (30) concluded, for example, that organizational downsizing may increase sickness absence and the risk of death from cardiovascular disease among employees who keep their jobs. In another study, Kivimäki and his colleagues (28) found that downsizing is a risk factor for musculoskeletal problems for those who remain in employment. Much of this risk appeared to be attributable to an increase in physical demands, but a reduction in skill discretion and job insecurity also contributed to this risk.

Nowadays, job insecurity is very prevalent in the workforce. In 1997, 29\% of US workers reported that it is somewhat or very likely that they will lose their jobs in the next couple of years. This figure constitutes an increase from the $15 \%$ in 1977 (32). Contingent workers (temporary and occasionally part-time employment), often contracted from outside agencies or independents, have less job security, as many organizations do not consider these workers as an intrinsic part of the organization (26). Such contingent workers seem to be a risk group for occupational stress. A study by Merllie \& Paoli (33) among European employees demonstrated that those who were employed by temporary agencies reported the highest work speed, the most frequent repetitive movements, the least control over their workpace, and the least work-related training. Employees with open-ended contracts scored the best in this respect, whereas those with fixed-term contracts held an in between position (34).

\section{New technology}

As with all technology, instruments, and devices, the appropriateness of information and communication technology depends largely on the way it is used (35). On one hand, technology facilitates the rapid diffusion of information and knowledge. It can increase comfort, speed, and performance. There is no doubt that it can also make job content more interesting while creating jobs that combine high demands with high skill discretion and decision latitude (36).

On the other hand, ICT can have an adverse impact on the psychosocial work environment and therefore amplify existing problems or create new problems (eg, repetitive strain injury). Since the early 1980s the computerization of many office and industrial functions has created considerable interest in the potential health and welfare effects of video work. Initially, such studies addressed direct physical health and safety impacts (eg, electromagnetic fields) or the ergonomic design of work stations (37). Later, also more indirect effects came into focus, as more studies concentrated on the potential impact of video display technology on the psychosocial work environment. For example, Aronsson [38, cited by Evans et al (37, p 18)] found that the introduction of 
new technology was associated with an increase in cognitive demands (attention, mental effort, concentration) and a decrease in the level of special knowledge required to carry out worktasks (deskilling). This trend appeared to be the most notable among low-status groups with less skilled task requirements.

Another problem relates to the task allocation in a man-machine system: which tasks are allocated to the machine and which to the task performer? An over-reliance on complex technology may lead to serious damage, as illustrated in the case of the USS-Vincennes. On 3 July 1988, this American Naval vessel shot down an Iranian airliner by mistake, killing 290 civilians. The utilization of extremely complex technology in a very stressful situation (a sea battle by remote control) clearly contributed to this tragedy.

A more common problem is the "information overflow" that characterizes current ICT usage. It seems as if there is a kind of autonomous force behind many of these ICT applications. Because of the technical possibility to have instant communication, we want or even demand instant communication. This situation leads to impatient senders who send their messages simultaneously by e-mail, phone, and fax ("Did you read my e-mail?").

This example makes it clear that ICT has major implications for work-related social interaction. For many modern employees, communication with the computer largely replaces communication directly with co-workers on the work floor since there is no objective need to leave the workstation if one needs information or contact. Everything needed is in the computer or can be made available through the computer (eg, on the Internet). In a similar vein, it is not uncommon for researchers to publish a scientific paper jointly or to organize a scientific conference with colleagues whom they have never met in person. ICT and computer work may also increase static load, as work is more and more sedentary. This trend bears the risk of "movement poverty".

Furthermore, it appears that e-mail contributes negatively to social intercourse at the workplace because email is an impersonal, low-threshold medium. E-mail disputes easily escalate because it may cause people to write things that they would prefer not to mention faceto-face.

Recently De Croon et al (39) published a review study in which they examined how three modern ICTbased and flexible office concepts [ie, office location (eg, telework office versus conventional office), office layout (eg, open layout versus cellular office), and office use (eg, fixed versus shared workplaces)] affect cognitive workload, workhours, communication, work autonomy, privacy, and interpersonal relations at work, as well as the short-term and long-term health and well-being reactions of office workers. The results of their study provide strong evidence that working in open workplaces reduces privacy and job satisfaction. Limited evidence is available showing that working in open workplaces intensifies cognitive workload and negatively affects interpersonal relations between employees, that close distances between workstations intensify cognitive workload and reduce privacy, and that desksharing improves communication.

New technology also influences human resource policies, especially the style of leadership. The utilization of ICT may presuppose another supervisory style (ie, performance management). Ever since the work of Frederick Taylor (40), traditionally many work organizations have focused on time management (being present at work). The time clock and time keeping are classical manifestations of time management. However, when workers and managers work out of sight of each other, traditional time management may fail, and so the emphasis may shift to performance management: management based on results. As can be noted in the discussion in the case of call centers, such performance management has two faces.

\section{Work-home interaction (due to changes in the workforce)}

Due to the increase in the number of dual-earning families, the availability of ICT, and the additional flexibility of work, the boundaries between the work and nonwork areas have changed.

This change has led to a large number of recent studies into work-home interaction, that is, "a process whereby one's functioning (and behavior) in one domain is influenced by (quantitative and qualitative) demands from the other domain [p 289]" (41). Modern views differentiate between the direction of influence (influence from work on private life and vice versa) and the quality of influence (negative versus positive influence) (42-44). Research has consistently demonstrated that negative influence from work is the most prevalent form of interaction and that this interference is reported more often by workers who are confronted with relatively high job pressure and relatively low levels of job control and job support $(41,44,45)$. Furthermore, previous research has provided evidence for strong crosssectional associations between negative work-home interaction and fatigue (43), as well as for relationships with decreased levels of psychological health across time $(46,47)$.

To enable employees to coordinate their work and domestic obligations better, many companies have introduced "work-home arrangements". National governments have also issued legislation in this area (48). Work-home arrangements introduced by companies or governments can be categorized into flexible work-home 
arrangements enlarging workers' temporal and spatial flexibility at work (eg, flextime, telework, part-time work) and into dependent-care work-home arrangements that make it possible for workers to combine their work and caring responsibilities (eg, subsidizing child care and allowing temporary leave periods for the care of dependent family members) (48). Employees in the United States who have more access to flexible work arrangements are significantly more satisfied with their jobs and are also more committed to their company (18). Few studies have addressed the extent to which (certain subgroups of) employees actually use such arrangements, whether the actual utilization of work-home arrangements is dependent on the organizational culture, and whether the utilization of such arrangements is related to (changes) in work-home interaction.

\section{New organizational practices: the call-center example}

A call center is a work environment in which the main business is mediated by computer and telephone-based technologies that enable the efficient distribution of calls (or allocation of outgoing calls) to available staff and permits customer-employee interaction to occur simultaneously with the use of display screen equipment and instant access to, and inputting of, information (49). Call centers are not radically new organizational practices. Although not labeled as such, emergency service telephone lines and customer help lines are examples of call centers that have existed for more than half a century. In addition, the early telephone operators, "the switch board girls" who made the connections between callers and receivers, were prototypical call-center employees. It was not unusual for these operators to connect 1200 telephone calls in an hour (ie, one call in every three seconds!). However, at that time (around 1890), their complaints in relation to repetitive strain injury received little attention, among others, because it was thought that these female operators threatened the position of male telegraph operators who lost their jobs due to the invention of the telephone (50).

Call centers may be conceptualized as a socio-technical system (51). "Technically" the increase in call centers is mainly attributable to technologies that combine call management systems (eg, automatic call distribution systems) with networking information technologies (49). "Socially" call centers are being implemented because companies want to minimize labor costs, improve customer service, or sell new products or services.

Holman (49) has summarized the existing studies that related several characteristics of call-center work to employee health and well-being. From his overview, it follows that call-center technologies can be used in different ways. One way of cutting costs is to employ cheaper, less skilled staff. This is considered an attractive option in the service sector, where the costs of labor constitute the highest cost type $(49,52)$. At this "Taylor-end" of the continuum, jobs are unskilled, repetitive, and monotonous. Calls need to be completed within a short period of time, conducted in accordance with a predescribed script that exactly prescribes the opening, closing, and, sometimes, total call. Freedom at work and social interactions at work are severely restricted.

These tasks are really similar to the "one best way" proposed by Frederick Taylor and Frank Gilbreth, for example, for bricklaying or shoveling. Their one best way emerged from selecting a limited number of skillful job performers, studying the exact series of elementary operations or motions each man made, using a stopwatch to study the time required to make each of these elementary movements, and then selecting the quickest way of doing each element of work, eliminating all false, slow, and useless movements, and collecting into one series the quickest and best movements. This best method then became standard (40, p 45) and was made obligatory for every worker after training.

Along this tradition, individual performance is monitored closely. Performance monitoring involves the observation of, recording of, and feedback on employee behavior. Direct observation, listening to calls, and customer surveys are traditional forms. More recent electronic performance monitoring involves the automatic and remote collection of quantitative data. Some callcenter technologies permit every call to be recorded (49). This type of mass service-call centers has led to their being labeled "electronic sweatshops" (53).

Schematically, at the other end of the continuum, is the "empowered job". This job is filled by a semi-professional customer service representative who has special knowledge and expertise with more control over the work approach and who provides a customized service. Such employees, for example, at a helpdesk, deal with a variety of calls and handle problems at their source. Calls are longer and nonstandardized, often except for the opening and closing remarks. This latter type of center has also been termed high commitment service (49). Note that this term seems to mix up the description and preferred outcomes of such centers. There are indications in the literature that, in such centers, performance monitoring is at a lower level and is not so much used to discipline and control employees or to train and develop competences. It is clear that, from a psychosocial point of view, the latter type of call centers is to be preferred.

\section{Overtime work}

Overtime work is an example of quantitative flexibility. It can be defined as workhours that exceed contractual hours. The main motive for the implementation of 
overtime work is to adjust labor capacity flexibly to an increase in demand for products and services. Although also part-time employees can work overtime, most studies on overtime work have addressed full-time employees, and therefore the concepts of overtime work and long workhours have often been used interchangeably (54). Again, in a way, there is nothing new under the sun. Early accounts of extremely long workhours stem from the Roman Empire, for example, concerning the army, midwives, and physicians [55, cited by Thierry \& Meijman (24)]. Centuries later, in British and French companies at the end of the 18th century, work began around 0500 or 0600 and ended around 2000 or 2100 , depending on the season. Two hours were included for breaks. Workers (men, women, children) were required to work an average of 12 to 13 hours a day. During the 20th century, average worktime decreased gradually, in most countries as a result of social action. Despite this gradual decrease in the official length of the workday and workweek, overtime work is a common phenomenon all over the world. Merllie \& Paoli (33) showed that $20 \%$ of the employees in the European Union worked an average of more than 44 hours a week. In Japan, workweeks that exceed 60 hours are no exception. This extreme type of overtime work can have severe health consequences and may eventually lead to death (karoshi) (56). In Japan, even a new word, "karojisatsu" (ie, a suicide attempt due to overwork), was created in 1997, and, in a civil case, a Japanese ad company paid the equivalent of more than one and a half million dollars to "karo-jisatsu" victims' parents (57).

In a recent review, van der Hulst (58) summarized the associations between long workhours and health, special attention being given to physiological recovery and behavioral lifestyle mechanisms that may explain the relationship. The 27 recent empirical studies that met her selection criteria showed that long workhours are associated with adverse health (cardiovascular disease, diabetes, disability retirement, self-reported physical health, fatigue). In another recent study among a nationally representative sample of working adults from the United States, jobs with overtime schedules were associated with a $61 \%$ higher injury hazard rate than jobs without overtime (59). Another notable study, by Dong (60), among a large sample of US construction workers, showed comparable results. Above 50 workhours a week, the injury risk was almost double that for "normal" (ie, less than 40) workhours.

Although there is a general consensus that extreme overtime has negative health consequences, studies on "moderate" overtime suggest that working overtime may also be related to work motivation. In a study by Beckers and her colleagues (61) among a representative sample of the Dutch full-time workforce, moderate overtime (an average of 3.5 hours weekly) appeared to be common, and these overtime workers appeared to be happy employees with attractive job characteristics. Much is still to be learned in this area of research. A better understanding of why (ie, under which circumstances) overtime work may have positive or negative outcomes with respect to health and well-being may well depend on the psychosocial profile of the overtime task. Crucial characteristics may be the number of overtime hours, recovery opportunities, incidental versus chronic overtime work, paid versus unpaid overtime, obligatory versus self-chosen overtime, and the content of the overtime actions (quality of worklife, eg, demands, variety, control). It can be expected that better designs and better data will contribute to a better understanding of the relations between overtime work, work characteristics, health, and work motivation (61).

\section{Discussion}

Changes in the economic, political, technological, and social landscape have changed the world. Accordingly, the world of work has changed. While responding and anticipating these changes, companies amplified and combined existing organizational practices and developed new forms of such patterns. "New" systems of work organization have surely become more prevalent. The pillars underneath these new practices are a striving for cost effectiveness, profit and flexibility, and the utilization of new technology. These practices do not represent a radical change across the whole economy. Some practices are new; others have already been utilized for many years or are extensions of old principles and ideas. Many organizations utilize combinations of these practices.

Due to the aforementioned changes, job characteristics (the work itself, social relationships at work, work conditions, terms of employment) have really changed. Compared with workers 30 years ago, modern employees increasingly work in offices and in the service sector, instead of in industry or in agriculture, and with information or clients instead of with tangible objects. The most striking development is the changing nature of work itself, from physical to mental. Due to a systematic intensification of work, the psychosocial workload has increased. Today, for many employees, work poses primarily mental and emotional demands. This change implies that interpersonal skills (communication) and cognitive skills (eg, decision making) will be increasingly important in modern organizations. At the same time, job and work security has decreased. Landsbergis (62, p 64) points to the fact that European surveys in the year 2000 showed continuing increases in work intensity and job demands, but a leveling off of previously 
also increasing reports of autonomy (33). This finding suggests that, all in all, the psychosocial work quality of these workers has not improved. Another major feature is the blending of work and family life.

With Holman \& Wood (11, p 7-8), I conclude that there is no straightforward relationship between a work practice and its effects. A modern work practice can have both positive and negative effects. "The effects of a flexible working practice are dependent on how it is implemented, designed and managed and are not solely dependent on some intrinsic feature of the working practice itself [p 7]" (11). Proponents (63) have argued that new systems of work organization offer increased flexibility, responsibility, and learning opportunities. Others have been more critical, emphasizing the health risks related to these new work practices. Exemplary for the latter is the Tokyo Declaration (1998) formulated by 28 occupational health experts from the European Union, Japan, and the United States. These experts state that most of these developments are driven by economic and technological changes aimed at short-term productivity and profit gain. Unfortunately, not much well-designed empirical work has been carried out in this area. A notable exception is a study by Landsbergis et al (64), who reviewed the available evidence with respect to the impact of lean production and related new systems of work organization on worker health. Much of this early work has been done in the automobile industry. Landsbergis and his co-workers have demonstrated that the limited research available provides little evidence that manufacturing workers are "empowered" under lean production. Rather, they conclude that lean production in automobile manufacturing creates intensified workpaces and demands, whereas decision latitude remains low. It follows from this review that there is indeed reason to be concerned about the way these systems may affect job characteristics, job stress, and health, thus rendering support to the pessimistic conclusions of the Tokyo Declaration.

It should also be noted that the organization of work changes can amplify traditional occupational health risks. [See also the chapter by Evans et al (37) for an early and thorough discussion of possible interactions between psychosocial and physical work characteristics.] For example, such changes may influence the level of exposure to physical hazards on the job. Extended workhours (overtime work) may increase the exposure to toxic substances (26). Little is known with respect to the acceptability of extended work periods, as traditionally maximum thresholds (eg, Dutch maximum admissible concentrations of toxic agents at the workplace) have been based on the notion of regular day work (24). In a similar vein, a higher prevalence of night work may increase the number of occurrences of work-related violence, and the like.

\section{Some research challenges}

The image of the prevalence of new work practices and their impact on the health and safety of today's employees remains scattered. Therefore, in the United States, the National Occupational Research Agenda (NORA) set up a multidisciplinary team of researchers and practitioners from government, industry, labor, and the academic world to develop a comprehensive research agenda for investigating and reducing occupational safety and health risks associated with the changing organization of work (12). Sauter and his colleagues (12) conclude that "revolutionary changes in the organization of work have far outpaced our knowledge about the implications of these changes for the quality of working life and for safety and health on the job [p v]". The following four research and development needs are identified in their research agenda: (i) improved surveillance and monitoring studies to better track how the organization of work is changing, (ii) accelerated research on safety and health implications of the changing organization of work, (iii) increased research focus on organizational interventions to protect safety and health, and (iv) steps to formalize and nurture the organization of work as a distinctive field in occupational safety and health.

Each of these recommendations is detailed in the NORA report. It is notable that, to a considerable extent, these NORA recommendations align with those from the Tokyo Declaration.

The NORA recommendations are very well in place and constitute a clear and useful research agenda for the near future. These recommendations strongly converge with research priorities that were recently listed by Kompier \& Taris (10). Furthermore, I would like to add three comments or recommendations. First, as previously noted, there are clear indications that contingent, marginal part-time, temporary, undocumented workers and those with a lower socioeconomic status may be facing greater health risks as a result of economic trends and trends in the organization of work. Special attention needs to be paid to the work context and content of these marginal workers. [See also the report by Landsbergis (62).] In a similar vein, more occupational stress studies are needed among workers in poorer and less developed countries.

Second, the NORA recommendations emphasize the (potential) safety and health risks of new work practices, and there is good reason to do so. However, I have emphasized that new modern practices are not good or bad per se. Their impact depends on their design and implementation (content and process). Accordingly, I propose that the potential positive effects of new modern practices be taken into account, possible motivational contributions to skill-discretion and skill development, 
increased self-reliance and personal initiative, and the conditions under which these positive outcomes emerge.

Third, as also stated by Schaufeli (65, p 506), this research agenda is primarily about the improvement of occupational safety, health, and well-being. It does not address more fundamental research questions into the physiological and psychological processes and mechanisms that may explain how the organization of work affects the health and safety of employees. Examples of such underlying mechanisms are the physiological recovery and behavioral lifestyle mechanisms that were proposed by van der Hulst (58). More fundamental research in order to further clarify the black box between exposure to (combinations of) certain job characteristics and health and safety outcomes should be a high priority when future studies on occupational stress are considered (10).

\section{Acknowledgments}

I would like to thank Sabine Geurts and Toon Taris for their comments on an earlier draft of this paper.

\section{References}

1. Katz D, Kahn RL. The social psychology of organizations. 2nd ed. New York (NY): John Wiley \& Sons; 1978.

2. Gardell, B. Alienation and mental health in the modern industrial environment. In: Levi L, editor. Society, stress and disease; vol 1: the psychosocial environment and psychosomatic diseases. London: Oxford University Press; 1971. p 146-66.

3. Levi L. Stress and distress in response to psycho-social stimuli. Oxford: Pergamon Press; 1972.

4. Schabracq MJ, Winnubst JAM, Cooper CL, editors. The handbook of work \& health psychology. Chichester (UK): John Wiley \& Sons; 2003.

5. Quick JC, Tetrick LE, editors. Handbook of occupational health psychology. Washington (DC): American Psychological Association; 2003.

6. Barling J, Kelloway EK, Frone MR, editors. Handbook of work stress. Thousand Oaks (CA): Sage; 2005.

7. European Organizations of Employers and Employees. Framework agreement on work-related stress. Brussels: European Trade Union Confederation (ETUC); 2004.

8. European Foundation for the Improvement of Living and Working Conditions. Work-related stress and industrial relations. Dublin: European Foundation for the Improvement of living and Working Conditions; 2001.

9. Kompier M. Job design and well-being. In: Schabracq M, Winnubst J, Cooper C, editors. The handbook of work \& health psychology. Chichester (UK): Wiley; 2003. p 429-54.

10. Kompier MAJ, Taris TW. Psychosocial risk factors and workrelated stress: state of the art and issues for future research. In: Antoniou ASG, Cooper CL, editors. Research companion to organizational health psychology. Bodwin (UK): MPG Books;
2005. p 59-69.

11. Holman D, Wood S. The new workplace: an introduction. In: Holman D, Wall TD, Clegg CW, Sparrow P, Howard A, editors. The new workplace: a guide to the human impact of modern working practices. Chichester (UK): John Wiley \& Sons; 2003. p 3-15.

12. Sauter S, Brightwell W, Colligan M, Hurrell J, Katz T, LeGrande $\mathrm{D}$, et al. The changing organization of work and the safety and health of working people. Cincinnati $(\mathrm{OH})$ : National Institute for Occupational Safety and Health (NIOSH); 2002.

13. Sparrow P. The future of work. In: Holman D, Wall TD, Clegg CW, Sparrow P, Howard A, editors. The new workplace: a guide to the human impact of modern working practices. Chichester (UK): John Wiley \& Sons; 2003. p 371-91.

14. Cascio WF. Changes in workers, work, and organizations. In: Borman WC, Ilgen DR, Klimoski RJ, Weiner IB, editors. Handbook of psychology, volume 12: industrial and organizational psychology. Hoboken (NJ): John Wiley \& Sons; 2003. p 401-22.

15. Cascio W. Managing human resources: productivity, quality of worklife, profits. New York (NY): Mc Graw-Hill, 1995.

16. European Commission. Key facts and figures about Europe and the Europeans. Brussels: European Commission Directorate-General for Press and Communication Publications; 2005.

17. Furnham A. The psychology of behaviour at work. Hove \& New York: Psychology Press; 2005.

18. Bond JT, Thompson C, Galinsky E, Protta D. Highlights of the national study of the changing workforce. New York (NY): Families and Work Institute; 2003.

19. Paoli P, Merllie D. Third European survey on working conditions. Dublin: European Foundation for the Improvement of Living and Working Conditions; 2001.

20. Di Natale M. Characteristics of and preferences for alternative work arrangements, 1999. Mon Labor Rev. 2001;124(3):2849.

21. Frese M. The changing nature of work. In: Chmiel N, editor. Introduction to work and organizational psychology. Oxford: Blackwell; 2000. p 424-39.

22. Sparrow PR, Marchington M, editors. Human resource management: the new agenda. London: Financial Times Pitman Publications; 1998.

23. Holman D, Wall TD, Clegg CW, Sparrow P, Howard A, editors. The new workplace: a guide to the human impact of modern working practices. Chichester (UK): John Wiley \& Sons; 2003.

24. Thierry HK, Meijman TF. Time and behavior at work. In: Triandis HC, Dunnette MD, Hough LM, editors. Handbook of industrial and organizational psychology; volume 4. 2nd ed. Palo Alto (CA): Consulting Psychologists Press; 1994. p 341413.

25. Worrall L, Cooper CL. Quality of working life survey. London: Institute of Management; 1998.

26. Sparks K, Faragher B, Cooper CL. Well-being and occupational health in the 21th century workplace. J Occup Organ Psychol. 2001;74:489-509.

27. Tetrick LE. Linkages between organizational restructuring and employees' well-being. J Tokyo Med Univ. 2000;58:35763.

28. Kivimaki M, Vahtera J, Ferrie JE, Hemingway H, Pentti J. Organizational downsizing and musculoskeletal problems in employees: a prospective study. Occup Environ Med. 2001;58:811-7.

29. Kalimo R, Taris TW, Schaufeli WB. The effects of past and 
anticipated future downsizing on survivor well-being: an equity perspective. J Occup Health Psychol. 2003;8(2):91-109.

30. Vahtera J, Kivimaki M, Pentti J, Virtanen M, Virtanen P, Ferrie JE. Organizational downsizing, sickness absence, and mortality: 10-town prospective cohort study. BMJ. 2004;328: 555-7.

31. Vahtera J, Kivimaki M, Forma P, Wikstrom J, Halmeenmaki T, Linna A, Pentti J. Organizational downsizing as a predictor of disability pension: the 10-town prospective cohort study. $\mathrm{J}$ Epidemiol Community Health. 2005;59:238-42.

32. Bond T, Galinsky E, Swanberg JE. The 1997 national study of the changing workforce. New York (NY): Families and Work Institute; 1998.

33. Merllie D, Paoli P. Ten years of working conditions in the European Union. Dublin: European Foundation for the Improvement of Living and Working Conditions; 2001.

34. Kompier M. Dealing with workplace stress. In: Cooper CL, editor. Handbook of stress medicine and health. 2nd ed. Boca Raton (CA): CRC Press; 2005. p 349-74.

35. Hamborg K-C, Greif S. New technologies and stress. In: Schabracq M, Winnubst J, Cooper C, editors. The handbook of work \& health psychology. Chichester (UK): Wiley; 2003. p 209-35.

36. Landy FJ, Conte JM. Work in the 21st century: an introduction to industrial and organizational psychology. New York (NY): McGraw Hill; 2004.

37. Evans GW, Johansson G, Carrere S. Psychosocial factors and the physical environment: interrelations in the workplace. In: Cooper CL, Robertson IT, editors. International review of industrial and organizational psychology; vol 9. Chichester (UK): John Wiley \& Sons; 1994. p 1-29.

38. Aronsson G. Changed qualification demands in computermediated work. Appl Psychol-Int Rev. 1989;38: 57-71.

39. De Croon EM, Sluiter JK, Kuijer PPFM, Frings-Dresen MHW. The effect of office concepts on worker health and performance: a systematic review of the literature. Ergonomics. 2005;48(2):119-34.

40. Taylor FW. Scientific management. New York (NY): Harper \& Brothers; 1911.

41. Geurts S, Demerouti E. Work/non-work interface: a review of theories and findings. In: Schabracq M, Winnubst J, Cooper C, editors. The handbook of work \& health psychology. Chichester (UK): Wiley; 2003. p 279-312.

42. Grzywacz JG, Marks NF. Reconceptualizing the work-family interface: an ecological perspective on the correlates of positive and negative spillover between work and family. J Occup Health Psychol. 2000;5:111-26.

43. Geurts S, Taris TW, Kompier MAJ, Dikkers JSE, Van Hooff MLM, Kinnunen UM. Work-home interaction from a work psychological perspective: development and validation of a new questionnaire, the SWING. Work Stress. 2005;19(4): 319-39.

44. Byron K. A meta-analytic review of work-family conflict and its antecedents. J Vocat Behav. 2005;67:169-98.

45. Frone MR. Work-Family balance. In: Quick JC, Tetrick LE, editors. Handbook of occupational health psychology. Washington (DC): APA; 2003. p 143-62.

46. Demerouti E, Bakker AB, Bulters AJ. The loss spiral of work pressure, work-home interference and exhaustion: reciprocal relations in a three wave study. J Vocat Behav. 2004;64:131-
49.

47. van Hooff M, Geurts SAE, Taris TW, Kompier MAJ, Dikkers JSE, Houtman ILD, et al. Disentangling the causal relationships between work-home interference and employee health. Scand J Work Environ Health. 2005;31(1):15-29.

48. Dikkers J, Geurts S, Den Dulk L, Peper B, Kompier M. Relations among work-home culture, the utilization of workhome arrangements, and work-home interference. Int J Stress Manage. 2004;11(4):323-45.

49. Holman D. Call centres. In: Holman D, Wall TD, Clegg CW, Sparrow P, Howard A, editors. The new workplace: a guide to the human impact of modern working practices. Chichester (UK): John Wiley \& Sons; 2003. p 115-34.

50. Dembe AE. The changing nature of office work: effects on repetitive strain injuries. Occup Med. 1999;14(1):61-72.

51. Cherns AB. Principles of sociotechnical design revisited. Hum Relat. 1987;40:153-62.

52. Batt R. Strategic segmentation in front line services: matching customers, employees, and human resource systems. Int J Hum Resour Manage. 2000;11:540-61.

53. Garson B. The electronic sweatshop: how computers are transforming the office of the future into the factory of the past. New York (UK): Simon \& Schuster; 1988.

54. Spurgeon A, Harrington JM, Cooper CL. Health and safety problems associated with long working hours: a review of the current position. Occup Environ Med. 1997;54:367-75.

55. Scherrer J. Man's work and circadian rhythm through the ages. In: Reinberg A, Vieux N, Andlauer P, editors. Night and shift work: biological and social aspects. Oxford: Pergamon Press; 1981.

56. Haratani T. Karoshi: death from overwork. In: Stellman JM, editor. Encyclopedia of occupational health and safety. 4th ed. Geneva: International Labour Office; 1998. p 518-9.

57. Shima S, Satoh E. Occupational health psychology in Japan. Occup Health Psychol. 2005;3:18-21.

58. van der Hulst M. Long workhours and health. Scand J Work Environ Health. 2003;29:171-88.

59. Dembe AE, Erickson JB, Delbos RG, Banks SM. The impact of overtime and long work hours on occupational injuries and illnesses: new evidence from the United States. Occup Environ Med. 2005;62:588-97.

60. Dong X. Long workhours, work scheduling and work-related injuries among construction workers in the United States. Scand J Work Environ Health. 2005;31(5):329-35.

61. Beckers DGJ, Van der Linden D, Smulders PGW, Kompier MAJ, Van Veldhoven M, Van Yperen NW. Working overtime hours: relations with fatigue, work motivation, and the quality of work. J Occup Environ Med. 2004;46(12):1282-9.

62. Landsbergis $P$. The changing organization of work and the safety and health of working people: a commentary. J Occup Environ Med. 2003e;45(1):61-72.

63. Womack JP. The psychology of lean production. Appl Psychol-Int Rev. 1996;45:119-52.

64. Landsbergis PA, Cahill J, Schnall P. The impact of lean production and related new systems of work organization on worker health. J Occup Health Psychol. 1999;4(2):108-30.

65. Schaufeli WB. The future of occupational health psychology. Appl Psychol-Int Rev. 2004;53(4):502-17.

Received for publication: 31 January 2006 